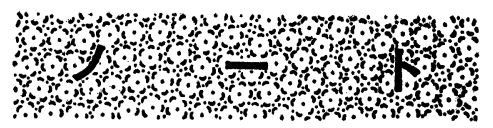

\title{
腐敗魚介類から分離した細菌のタンパク質及び脂肪分解能*1
}

(昭和 61 年 7 月 29 日受理)

小畠満子*2 外海泰秀*3 伊藤誉志男 ${ }^{* 3}$

\section{Proteolytic and Lipolytic Activities of Bacteria Isolated from Spoiled Seafoods}

\author{
Michiko Kobatake*2, Yasuhide TonogaI*3 and Yoshio ITo*3 \\ (*2National Institute of Hygienic Sciences: 1-18-1, Kamiyoga, Setagaya-ku, Tokyo, \\ Japan; ${ }^{* 3}$ National Institute of Hygienic Sciences, Osaka Branch: \\ 1-1-43, Hoenzaka, Higashi-ku, Osaka, Japan)
}

Four bacterial strains isolated from spoiled seafoods were identified, and their growth temperature ranges were determined. Proteolytic activity on nutrient agar plus $1 \%$ skim milk and lipolytic activity on butterfat in Crossley's agar were determined under various conditions of incubation for 2 weeks at 5,15 and $25^{\circ} \mathrm{C}$.

Pseudomonas fuorescens S-1 was isolated at the cell number of $2.4 \times 10^{5}$ per gram from a spoiled common mackerel (Scomber japonicus). This strain was a gram negative aerobic rod with polar flagella, and produced diffusible fluorescent pigment and arginine dihydrolase. The strain was psychrotrophic, having a growth temperature range from 0 to $30^{\circ} \mathrm{C}$ with the optimum temperature at about $25^{\circ} \mathrm{C}$. The strain showed both proteolysis and lipolysis within 2 days at $25^{\circ} \mathrm{C}$, within 4 days at $15^{\circ} \mathrm{C}$, and within 14 days at $5^{\circ} \mathrm{C}$.

Bacillus subtilis S-8 was isolated at the cell number of $1.1 \times 10^{8}$ per gram from a spoiled neon flying squid (Ommastraphes bartrami). This strain was a gram positive endosporeforming rod, and hydrolyzed gelatin, starch and casein. The strain showed both proteolysis and lipolysis within one day at $25^{\circ} \mathrm{C}$, within 3 days at $15^{\circ} \mathrm{C}$, and within 4 days at $5^{\circ} \mathrm{C}$.

Staphylococcus epidermidis S-6 was isolated at the cell number of $5.5 \times 10^{7}$ per gram from a spoiled black tiger shrimp (Penaeus monodon). This strain was a gram-positive yellow pigmented coccus. It grew on mannitol salt agar, but it did not produce lecithinase or coagulase. Both proteolysis and lipolysis of the strain were positive within 2 days at $25^{\circ} \mathrm{C}$. The proteolysis at 5 and $25^{\circ} \mathrm{C}$ was negligible.

Alcaligenes sp. S-4 was isolated at the cell number of $6.1 \times 10^{6}$ per gram from a spoiled black tiger shrimp. This strain was a gram negative aerobic coccal rod with peritrichous flagella. Its coenzyme Q system was Q-8, its GC content of DNA was $57.8 \mathrm{~mol} \%$. The strain demonstrated neither proteolysis nor lipolysis.

These 4 bacterial strains will be employed as test strains for microbiological and chemi-

\footnotetext{
*1 食品の腐敗に関する研究（第 3 報）

*2 国立衛生試験所：東京都世田谷区上用賀 1-18-1

*3 国立衛生試験所大阪支所：大阪市東区法円坂 1-1-43
} 
cal analysis in further investigations on spoilage of seafoods.

(Received July 29, 1986)

Key words: 腐敗魚介類 spoiled seafoods; 腐敗細菌 spoilage bacteria; Pseudomonas fuorescens; Bacillus subtilis; タンパク質分解能 proteolytic activity; 脂肪分解能 lipolytic activity

\section{緒言}

低温で流通または長期貯蔵される食品は低温微生物に よって污染される機会が多い，特にタンパク質及び脂肪 分解能を有する低温細菌群の存在は, 変敗, 腐敗との関 連において食品衛生上重視されている. そのため, 細菌

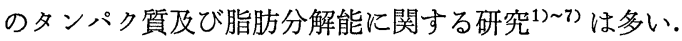
たとえば，タンパク質及び脂肪分解能陽性細菌の各種食 品に护る分布状況, あるいは培養温度別, 細菌菌属別 の出現頻度などについて詳しく調べられている。しか し, 酵母のタンパク質及び脂肪分解能に関する研究は少 なく, 著者らの低温酵母についての報告 ${ }^{8)}$ の他に, 水・ 畜産食品由来の未同定酵母についての報告4),5),77,9) が少 数ながらみられるに過ぎない。まして，タンパク質及び 脂肪分解能を酵母菌種と細菌菌種間で比較した研究は見 当らない.

本報では, 腐敗魚介類から主要な細菌を分離, 同定し, 発育温度特性, 並びに $5^{\circ}, 15^{\circ}, 25^{\circ}$ 培養におけるタン パク質及び脂肪分解能を調べ，前報8) で得られた酵母の 成績と比較しながら検討したので報告する.

\section{実験方法}

\section{1. 供試試料}

市販の生鮮マサバ 1 尾, 冷凍ウシェビ（ブラックタイ ガーシュリンプ） 3 尾，及び冷凍ムラサキイカ $50 \mathrm{~g}$ を 供試試料とした. (Table 1)

\section{2. 魚介類の腐敗}

生鮮マサバ及び室温 $\left(17^{\circ}\right)$ で解凍したウシェビとム ラサキイカの筋肉部分のみを用いた. ムラサキイカの筋 肉は $100^{\circ}$ で 3 分間加熱した. それぞれを $25^{\circ}$ の恒温器 に入れ，腐敗するまで放置した.

\section{3. 細菌の分離}

腐敗試料 $10 \mathrm{~g}$ を隇菌生理食塩液 $90 \mathrm{ml}$ に採取し, ワ ーリングブレンダーで磨砕してこれを原液とし，10倍希 釈法により, 生菌数測定用標準寒天培地 (栄研化学 (株) 製）平板上に塗抹した。これらを $25^{\circ}$ で 7 日間培養し， 各試料別に発生した集落のうち出現頻度の高い集落の代 表 1 集落を釣菌し, 4 菌株の細菌を分離した.

\section{4. 分離細菌の同定}

分離細菌の同定は主として, Bergey's Manual of Determinative Bacteriology ${ }^{10)}$ (第 8 版), Bergey's Manual of Systematic Bacteriology (第 1 巻)，「医学 細菌同定の手引き」 ${ }^{12)}$ (第 2 版), 「微生物の 分類 と同 定」13) (下) などに準じた. 同定のための培養温度は $25^{\circ}$ で行った.

運動性は半流動寒天高層, Craigie の方法 ${ }^{12}$ 及び懸滴 法 ${ }^{13)}$ などにより観察した。色素生成試験にはキング A及 びB培地（日水製薬）を，fruity odor の観察 ${ }^{14)}$ には羊 血液寒天培地（日水製薬）を用いた。嫌気性発育はダー ラム管入りブドウ糖ブイヨン ${ }^{12)} に$ 接種し，ガスパック嫌 気システム $(\mathrm{BBL})$ で嫌気培養を行った. $7 \%$ 塩化ナト リウム要求試験は $7 \%$ 塩化ナトリウム加 Nutrient broth (Difco) を用いた. ブドウ球菌用培地としてはマ ンニット食塩培地（日水製薬）を用いた．OF テストは Hugh らの方法 ${ }^{12)}$, チトクロームオキシダーゼ試験は Kovacs の方法 ${ }^{12)}$, アルギニンの分解試験は Thornley の方法 ${ }^{12)}$ ，コアグラーゼ産生試験は Cowan の方法 ${ }^{12)}$, ゼラチンの液化は Frazier の方法 ${ }^{12)}$, 脱窒反応は駒形

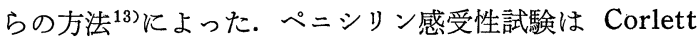
らの方法 ${ }^{15)}$ にった． 糖から酸の産生は, Smith らの糖 加アンモニウム塩培地 $(\mathrm{ASS})^{12)}$, 炭素化合物の利用は駒 形らの培地 ${ }^{13)}$ を用いて試験した. キノンの抽出は山田の

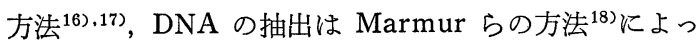
た.

\section{5. 生育温度試験}

標準寒天培地上で $25^{\circ} ， 4$ 日間の前培養を行った分離 細菌菌株を同培地の斜面に接種し, $0^{\circ}, 5^{\circ}, 10^{\circ}$ で 2 週 間, $15^{\circ}, 20^{\circ}, 25^{\circ}, 30^{\circ}, 37^{\circ}, 42^{\circ}$ で 1 週間培養し, 生 育状態を観察した. $0^{\circ} \sim 10^{\circ}$ 培養にはインキュベーター MIR-150 (三洋電機 (株) 製) を使用した.

\section{6. タンパク質分解能試験}

タンパク質分解能試験には $10 \%$ 脱脂乳 (Difco) 液を 10\%の割合に加えた標準寒天培地を用いた．培養及び 判定は前報8) と同様に行った.

Table 1. Seafood Samples Used for Isolation of Bacteria and Spoilage Examinations

\begin{tabular}{|c|c|c|c|}
\hline Japanese name & English name & Scientific name & Fishing ground \\
\hline Masaba & Common mackerel ${ }^{a}$ ) & Scomber japonicus & Japan \\
\hline Ushi-ebi & Black tiger shrimp $\left.{ }^{b}\right)$ & Penaeus monodon & Australia \\
\hline Murasaki-ika & Neon flying squid $\left.{ }^{b}\right)$ & Ommastraphes bartrami & Japan \\
\hline
\end{tabular}

a) Fresh; b) frozen 
Table 2. Morphological and Biochemical Characteristics of Bacteria Isolated from Spoiled Seafoods

\begin{tabular}{|c|c|c|c|c|}
\hline Characteristics & $\begin{array}{l}\text { Pseudomonas } \\
\text { fuorescens } \\
\text { S-1 }\end{array}$ & $\begin{array}{l}\text { Bacillus subtilis } \\
\text { S-8 }\end{array}$ & $\begin{array}{c}\text { Staphylococcus } \\
\text { epidermidis } \\
\text { S.6 }\end{array}$ & $\begin{array}{c}\text { Alcaligenes sp. } \\
\text { S.4 }\end{array}$ \\
\hline Form & rod & rod & coccus & coccal rod \\
\hline Gram stain & - & + & + & - \\
\hline $\begin{array}{l}\text { Capsule } \\
\text { Flagella }\end{array}$ & - & - & - & - \\
\hline $\begin{array}{l}\text { Flagella } \\
\text { Spore }\end{array}$ & $\pm^{a)}$ & $\begin{array}{l}+b) \\
t\end{array}$ & - & $+t^{b}$ \\
\hline $\begin{array}{l}\text { Spore } \\
\text { Motility }\end{array}$ & $\bar{t}$ & $\begin{array}{l}+ \\
t\end{array}$ & $\overline{-}$ & $\bar{t}$ \\
\hline & + & & - & \pm \\
\hline $\begin{array}{l}\text { Fluorescent pigment } \\
\text { Pyocianin production }\end{array}$ & - & $\overline{-}$ & $\overline{-}$ & $\overline{-}$ \\
\hline $\begin{array}{l}\text { Pyocianin production } \\
\text { Fruity odor }\end{array}$ & $\mathrm{NT}^{\mathrm{d})}$ & $\overline{N T}$ & $\overline{N T}$ & $\overline{-}$ \\
\hline Growth at: & & & & \\
\hline $5^{\circ} \mathrm{C}$ & + & - & - & - \\
\hline $\begin{array}{l}37^{\circ} \mathrm{C} \\
42^{\circ} \mathrm{C}\end{array}$ & - & + & + & + \\
\hline $\begin{array}{l}42^{\circ} \mathrm{C} \\
\text { Growth in anaerobic agar }\end{array}$ & - & \pm & $\begin{array}{l}+ \\
+\end{array}$ & - \\
\hline $\begin{array}{l}\text { Growth in anaerobic agar } \\
\text { Growth without added } \mathrm{NaCl}\end{array}$ & $\bar{t}$ & $\bar{t}$ & $\begin{array}{l}+ \\
+\end{array}$ & $\bar{t}$ \\
\hline & - & + & + & + \\
\hline Growth on mannitol salt agar & NT & NT & + & NT \\
\hline $\begin{array}{l}\text { Acid from glucose (OF test): } \\
\text { aerobic }\end{array}$ & + & + & & \\
\hline anaerobic & I & + & $\begin{array}{l}+ \\
+\end{array}$ & \pm \\
\hline Catalase & + & + & + & + \\
\hline Cytochrome oxidase $^{()}$ & + & + & - & + \\
\hline Arginine dihydrolase & + & - & + & - \\
\hline Urease & - & - & + & + \\
\hline Coagulase & - & - & - & - \\
\hline Gelatin liquefaction & + & + & $\bar{z}$ & $=$ \\
\hline Starch hydrolysis & - & + & - & - \\
\hline Casein hydrolysis & + & + & \pm & $=$ \\
\hline Egg yolk reaction & + & $\bar{t}$ & $\bar{t}$ & $\overline{-}$ \\
\hline Nitrate reduction & - & $\stackrel{+}{\mathrm{NT}}$ & NT & - \\
\hline Denitrification & - & NT & - & 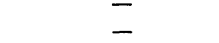 \\
\hline Indole production & - & $\overline{-}$ & - & $\Xi$ \\
\hline $\mathrm{H}_{2} \mathrm{~S}$ production & $\overline{-}$ & $\overline{-}$ & + & - \\
\hline $\begin{array}{l}\text { MR reaction } \\
\text { Acetoin production }\end{array}$ & - & + & + & - \\
\hline & & & & \\
\hline $\begin{array}{l}\text { Penicillin sensitivity: } \\
0.5 \mathrm{I} . \mathrm{U} . / \mathrm{ml}\end{array}$ & - & - & + & - \\
\hline $10 \mathrm{I} . \mathrm{U} . / \mathrm{ml}$ & - & - & + & - \\
\hline Acid from: ${ }^{e}$ & & & $t$ & + \\
\hline Glucose & $\begin{array}{l}t \\
t\end{array}$ & + & \pm & $\mathrm{NT}^{\top}$ \\
\hline $\begin{array}{l}\text { Arabinose } \\
\text { Xylose }\end{array}$ & + & & - & NT \\
\hline $\begin{array}{l}\text { Xylose } \\
\text { Fructose }\end{array}$ & + & + & + & NT \\
\hline Mannitol & + & + & + & NT \\
\hline Inositol & + & + & - & NT \\
\hline Sorbitol & + & + & - & NT \\
\hline Lactose & - & - & + & NT \\
\hline Maltose & - & + & \pm & NT \\
\hline Sucrose & - & t & + & \\
\hline Utilization of: ${ }^{\mathrm{f}}$ & & + & + & + \\
\hline $\begin{array}{l}\text { Glucose } \\
\text { Trehalose }\end{array}$ & $\begin{array}{l}t \\
+\end{array}$ & $\stackrel{+}{N T}$ & $\mathrm{NT}$ & - \\
\hline 2-Ketogluconate & + & NT & NT & + \\
\hline Citrate & + & - & $\overline{-}$ & + \\
\hline meso-lnositol & + & NT & NT & - \\
\hline L-Valine & + & NT & NT & - \\
\hline$\beta$-Alanine & + & NT & NT & - \\
\hline DL-Arginine & + & NT & NT & $\overline{0}$ \\
\hline $\begin{array}{l}\text { Coenzyme } \mathrm{Q} \text { system } \\
\mathrm{Mol} \% \mathrm{G}+\mathrm{C} \text { of } \mathrm{DNA}\end{array}$ & $\begin{array}{l}\text { NT } \\
\text { NT }\end{array}$ & $\begin{array}{l}\text { NT } \\
\text { NT }\end{array}$ & $\begin{array}{l}\text { NT } \\
\text { NT }\end{array}$ & $\begin{array}{l}\text { Q.8 } \\
57.8\end{array}$ \\
\hline
\end{tabular}

+, positive; -, negative; a) polar flagella; ${ }^{\text {b) }}$ peritrichous flagella; ${ }^{\text {c }}$ Kovac's; ${ }^{\text {d }}$ not tested; ${ }^{\text {o }}$ ASS

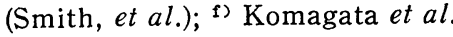


Table 3. Temperature Ranges of Growth of Bacteria Isolated from Spoiled Seafoods

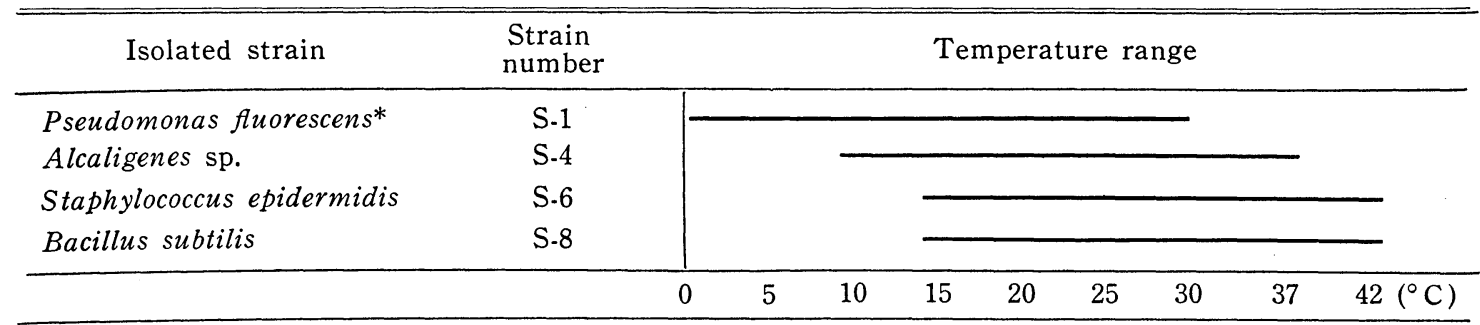

* Pseudomonas fluorescens isolated from a fresh common mackerel was psychrotrophic bacteria.

Table 4. Proteolytic and Lipolytic Activities of Bacteria Isolated from Spoiled Seafoods

\begin{tabular}{|c|c|c|c|c|c|c|c|c|c|c|c|c|c|c|c|c|c|c|}
\hline \multirow{3}{*}{ Species } & \multicolumn{18}{|c|}{ Incubation } \\
\hline & \multicolumn{6}{|c|}{$5^{\circ} \mathrm{C}$} & \multicolumn{6}{|c|}{$15^{\circ} \mathrm{C}$} & \multicolumn{6}{|c|}{$25^{\circ} \mathrm{C}$} \\
\hline & 1 & 2 & $\begin{array}{c}3 \\
(\mathrm{Da}\end{array}$ & $\begin{array}{c}4 \\
\mathrm{ys})\end{array}$ & 7 & 14 & 1 & 2 & $\begin{array}{c}3 \\
(\mathrm{Da}\end{array}$ & $\begin{array}{c}4 \\
\text { ys) }\end{array}$ & 7 & 14 & 1 & 2 & $\begin{array}{l}3 \\
\text { (Da) }\end{array}$ & $\begin{array}{c}4 \\
\text { ys) }\end{array}$ & 7 & 14 \\
\hline \multicolumn{19}{|l|}{ Proteolysis } \\
\hline B. subtilis & + & + & + & + & + & + & + & + & + & + & + & + & + & + & + & + & + & + \\
\hline P. fluorescens & - & - & - & - & + & + & - & - & - & + & + & + & - & + & + & + & + & + \\
\hline S. epidermidis & - & - & - & - & - & - & - & - & - & - & - & - & - & + & + & + & + & + \\
\hline Alcaligenes sp. & - & - & - & - & - & - & - & - & - & - & - & - & - & - & - & - & - & - \\
\hline \multicolumn{19}{|l|}{ Lipolysis } \\
\hline S. epidermidis & - & - & - & - & + & + & + & + & + & + & + & + & + & + & + & + & + & + \\
\hline P. fluorescens & - & - & + & + & + & + & - & + & + & + & + & + & + & + & + & + & + & + \\
\hline B. subtilis & - & - & - & + & + & + & - & - & + & + & + & + & + & + & + & + & + & + \\
\hline Alcaligenes sp. & - & - & - & - & - & - & - & - & - & - & - & - & - & - & - & - & - & - \\
\hline
\end{tabular}

$-=$ no hydrolysis; $+=$ weak or strong hydrolysis

\section{7. 脂肪分解能試験}

脂肪分解能試験にはクロスリ一寒天培地 (栄研化学 (株)）を用いた. 培養及び判定は前報8）と同様に行った.

\section{実 験 結 果}

1. 細菌の同定

分離細菌菌株の 形態学的, 生理 ・生化学的諸性質を

Table 2 に示した.

1) 分離菌株: S-1

本菌は悪臭の強い腐敗 マサバの筋肉から $2.4 \times 10^{5} / \mathrm{g}$ の菌数で分離された. 本菌は極鞭毛を有する運動性のグ ラム院性桿菌で，水溶性の黄色蛍光色素を産生した. ゼ ラチンの液化, カゼインの加水分解及び卵黄反応は陽性 であった. 食塩 $0 \%$ で発育したが，7\%では発育しなか った. ペニシリン耐性であった.これらの性質及び Table 2 の結果より, 本菌を Pseudomonas fuorescens (Trevisan) Migula と同定した.

\section{2) 分離菌株: S-8}

本菌は軟泥化した腐敗ムラサキイカの筋肉から $1.1 \times$ $10^{8} / \mathrm{g}$ の菌数で分離された. 本菌はグラム陽性の運動性 有芽胞桿菌で, 糖を発酵的に分解した。 ブドウ糖ブイヨ ンに打ける嫌気性発育は認められなかった. ゼラチンを
液化し，デンプンとカゼインを加水分解した。これらの 性質及び Table 2 の結果より, 本菌をBacillus subtilis (Ehrenberg) Cohn と同定した.

3) 分離菌株: S-6

本菌は弱いアンモニア臭を発生した腐敗ウシェビの筋 肉から $5.0 \times 10^{7} / \mathrm{g}$ の菌数で分離された．本菌はグラム 陽性の球菌で, 非水溶性の黄色色素を産生した。通性嫌 気性で, 糖を発酵的に分解した. マンニット加食塩培地 に発育したが，卵黄反応とコアグラーゼ産生試験は陰性 であった.これらの性質及び Table 2 の結果より本菌 を Staphylococcus epidermidis (Winslow and Win. slow) Evans と同定した.

4) 分離菌株: S-4

本菌は弱いアンモニア臭を伴った腐敗ウシェビの筋肉 から $6.1 \times 10^{6} / \mathrm{g}$ の菌数で分離された. 本菌は周鞭毛を 有するグラム陰性の球桿菌をたは短桿菌で, 硝酸塩の還 元及び脱窒反応は陰性であった．また，呼吸系キノン型 が Q-8, DNA の GC 含量が $57.8 \%$ であったことなど を総合して Alcaligenes 属に分類した. 更に化学分類 ${ }^{19)}$ を行い, 菌種名を決定したい。 


\section{2. 生育温度域の検討}

分離 4 菌種の生育温度域を Table 3 に示した.

P. fuorescens は $0^{\circ}$ から $30^{\circ}$ の温度範囲内で生育 し, 約 $25^{\circ}$ の至適温度を有する psychrotrophic bac-

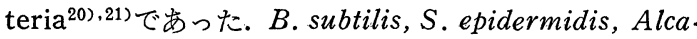
ligenes sp. は mesophilic bacteria であった.

\section{3. タンパク質分解能}

$5^{\circ}, 15^{\circ}, 25^{\circ}$ 培養に和ける分離 4 菌株のタンパク質 （カゼイン）分解能試験の成績を Table 4 に示した.

B. subtilis の分解能は強く, $5^{\circ}, 15^{\circ}, 25^{\circ}$ 培養の 1 日 目に陽性となった. P. fluorescens の分解能は B.subtilis よりは弱く, $5^{\circ}$ 培養の 7 日目, $15^{\circ}$ 培養の 4 日目, $25^{\circ}$ 培養では 2 日目に陽性となった. S. epidermidis の 分解能は弱く, $5^{\circ}, 15^{\circ}$ 培養では陰性であったが， $25^{\circ}$ 培養の 2 日目から陽性となった. Alcaligenes sp. は $5^{\circ}$ ， $15^{\circ}, 25^{\circ}$ 培養で陰性であった。

被験 4 菌種のタンパク質分解能は B.subtilis が最も 強く, 次いで P. Aluorescens, S. epidermidis, Alcaligenes sp. の順であった.

\section{4. 脂肪分解能}

$5^{\circ}, 15^{\circ}, 25^{\circ}$ 培養に拈ける分離 4 菌種の脂肪（バター 脂肪）分解能試験の成績を Table 4 に示した.

S. epidermidis は $5^{\circ}$ 培養の 7 日目, 及び $15^{\circ}, 25^{\circ}$ 培養の 1 日目に陽性となった. P. fluorescens は $5^{\circ}$ 培 養の 3 日目, $15^{\circ}$ 培養の 2 日目, $25^{\circ}$ 培養では 1 日目に, また, B. subtilis は P. fluorescens よりはやや遅く, $5^{\circ}$ 培養の 4 日目, $15^{\circ}$ 培養の 3 日目, $25^{\circ}$ 培養の 1 日 目に分解能陽性となった. Alcaligenes sp. は $5^{\circ}, 15^{\circ}$, $25^{\circ}$ 培養で陰性であった.

被験 4 菌種の脂肪分解能は P. fluorescens が最も強 く, 次いで B. subtilis, S. epidermidis, Alcaligenes sp. の順であった.

\section{考察}

P. fluorescens S-1 は多種類の炭素化合物を利用し, レシチナーゼを産生し, ゼラチンとカゼインを加水分解 するなど生理的に活性の強い菌種であり (Table 2), し かも低温で生育する特徵がある (Table 3). 古くから $P$. fluorescens は魚介類の主要な腐敗細菌として報告22) 28) されているが, 今回の分離株も生マサバが腐敗した場合 の優勢菌種であった。

B. subtilis S-8 b生理的に活性の強い菌種であった が, 発育温度域が P. fluorescens とは異なって拈り, P. fluorescens よりは高い温度 $\left(15^{\circ}\right.$ 以上) で発育増殖した (Table 3). 耐熱性の B. subtilis による加熱水産加工食 品の腐敗については種々報告29),30) されているが, 加熱 ムラサキイカを腐敗させた本実験に拈いても B. subti. lis S-8 が分離された.

S. epidermidis S-4 と Alcaligenes sp. S-4 は解凍 ウシェビを腐敗させた場合の優勢菌種であった. 解凍魚
の腐敗細菌フローラは鮮魚のそれとは異なって和り,

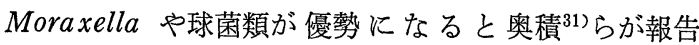
しているように, 著者らも球桿菌と球菌を分離した。こ れらの分離株は生理的には，さほど強い活性を示さなか った (Table 2).

今回の細菌 4 菌種と (Table 4), 今回と同一条件で試 験した前回 ${ }^{8)}$ の酵母 2 菌種のタンパク質及び脂肪分解能 を比較してみると,酵母 C. lipolytica は細菌 P. Aluorescens, B. subtilis, S. epidermidis, Alcaligenes sp. の4 菌種よりは強かった. 一方, 酵母 $T r$. cutaneum は $P$. fuorescens, B. subtilis, S. epidermidis の 3 菌種とほ ぼ同程度か, あるいは3 菌種よりは弱く, Alcaligenes sp. よりは強かった。すなわち，タンパク質・脂肪分解能は 酵母 C. lipolytica の方が細菌 P. fluorescens よりは強 く, P. fluorescens の方が酵母 Tr. cutaneum よりは 強く, Tr. cutaneum の方が細菌 Alcaligenes sp. より は強かった.このように酵母と細菌では菌種間でかなり の差が認められたので, 次回は酵母と細菌を隇菌魚介類 ホモジネートに単独で接種し, 詳細な比較実験を行いた い.

\section{要 約}

腐敗魚介類から分離した 4 菌株の細菌を同定し，生育 温度域を調べ， $5^{\circ}, 15^{\circ}, 25^{\circ}$ 培養に和けるタンパク質 (カゼイン) 及び脂肪 (バター脂肪) 分解能試験を行った.

1. P. fluorescens S-1 は生マサバが腐敗した場合の 優勢菌種であった. B. subtilis S-8 は加熱ムラサキイカ が, また S. epidermidis S-6 と Alcaligenes sp. S-4 は 解凍ウシェビが腐敗した場合の優勢菌種であった.

2.P. fluorescens は psychrotrophic bacteria であ り, B. subtilis, S. epidermidis, Alcaligenes sp. の 3 菌種は mesophilic bacteria であった.

3. P. fluorescens と B. subtilis は $5^{\circ}, 15^{\circ}, 25^{\circ}$ の 各培養温度でタンパク質・脂肪両分解能を示したが, Alcaligenes sp. は両分解能とも㓌性であった.S.epider midis $5^{\circ}$ と $15^{\circ}$ 培養では脂肪分解能のみ, $25^{\circ}$ 培養 ではタンパク質・脂肪両分解能を示した.

4. 分離細菌 4 菌種のタンパク質及び脂肪分解能の成 績と前報 ${ }^{8}$ で得られた酵母 2 菌種の成績とを比較した結 果, 細菌 S. epidermidis と酵母 Tr. cutaneum 2 菌種 間の, また細菌 P. fluorescens と酵母 C. lipolytica 2 菌 種間の各培養温度に和けるタンパク質及び脂肪分解能は ほぼ類似していた. B. subtilis の脂肪分解能は C. lipo. lytica のそれより弱く，Tr. cutaneum のそれより強か った. また Alcaligens sp. のタンパク質及び脂肪分解 能は酵母のそれらより弱かった。

本研究の要旨は日本食品衛生学会第50回学術講演会 (1985年10月，新潟）に拈いて発表した。

謝辞

稿を終るに当り, 御懇切な御助言及び試験成績の一部 
に御協力いただいた静岡大学 山田雄三教授, 東京大学 応用微生物研究所 山里一英助教授, (社) 日本食品衛生 協会研究所 河西 勉部長, 並びに終始御指導, 御鞭達 を賜わった東邦大学 海老沢功教授, 同 村井貞子助教 授, 国立衛生試験所 谷村顕雄副所長, 同 三瀬勝利部 長，同大阪支所．加納晴三郎元支所長に深謝致します。

\section{文献}

1) Sulzbacher, W. L.: Food Technol. 4, 386 390 (1950).

2）小久保弥太郎， 梅木富士郎，春田三佐夫：食衛 誌. 12，164～169 (1971).

3）橋本秀夫，村上行雄，太田欽幸：同上 14，168～ 172 (1973).

4) 日越博信, 浜田㬍一：同上 17，41 47 (1976).

5）鈴木 昭：モダンメディア別冊 23，244〜266 (1977).

6) Kraft, A. A., Rey, C. R.: Food Technol. 33, 66 71 (1979).

7） 久保倉洋子：食衛誌. $24,21 \sim 26$ (1983).

8）小畠満子, 倉田 浩：同上 24, 532 539 (1983).

9) Eklund, M. W., Spinelli, J., Miyauchi, D., Dassow, J.: J. Food Sci. 31, 424 431 (1966).

10) Buchanan, R. E., Gibbons, N. E.: "Bergey's Manual of Determinative Bacteriology" 8 th Ed., (1974) Williams \& Wilkins Co., Baltimore.

11) Krieg, N. R., Holt, J. G.: "Bergey's Manual of Systematic Bacteriology" Vol. 1, (1984) Williams \& Wilkins Co., Baltimore/London.

12) Cowan, S. T. (坂崎利一訳) : “医学細菌同定の手 びき”第 2 版（1974）近代出版.

13）駒形和男著，長谷川武治編：“改訂版 微生物の 分類と同定 下” p. 99〜161 (1975) 学会出版七 ンター。
14) Yamasato, K., Akagawa, M., Oishi, N., Kuraishi, H.: J. Gen. Appl. Microbiol. 28, 195 213 (1982).

15) Corlett, D. A., Lee, J. S., Sinnhuber, R. O.: Appl. Microbiol. 13, 808 817 (1965).

16) Yamada, Y., Aida, K., Uemura, T.: Agric. Biol. Chem. 32, 786 788 (1968).

17) Yamada, Y., Aida, K., Uemura, T.: J. Gen Appl. Microbiol. 15, 181 196 (1969)

18) Marmur, J., Doty, P.: J. Mol. Biol. 5, 109 118 (1962).

19）駒形和男編： “微生物の化学分類実験法” p. 131 282 (1982) 学会出版センター.

20) Morita, R. Y.: Bacteriol. Rev. 39, 144 167 (1975).

21) Morita, R. Y., Burton, S. D.: J. Bacteriol. 86, 1025 1029 (1963).

22）藤井建夫：東海水研報. 92, 1 63 (1977).

23) 相磯和嘉：食衛誌. 1，12１7 (1960).

24）中島正博：腐研報. 2, 4 35 (1949).

25) Ryser, E. T., Marth, E. H., Taylor, S. L.: J. Food Prot. 47, 378 380 (1984).

26) van Spreekens, K. J. A., Topepoel, L.: In. "Psychrotrophic Microorganisms in Spoilage and Pathogenicity" p. 283 294 (1981) Roberts, T. A., Hobbs, G., Christian, J. H. B. and Skovgard, N. Ed., Academic Press, London, New York, Toronto, Sydney, San Francisco.

27）奥積昌世：冷凍. 61，120～130 (1986).

28) Hunter, A. C.: J. Bacteriol. 7, 85 109 (1922).

29)，木俣正夫：日水誌， 16，52～54（1951).

30）赤松幹夫：日水誌. 26, 581 587 (1960).

31）奥積昌世，堀江 進，木村正幸，赤堀正光，川前 政幸：食衛誌. 13，418４21（1972）. 